\title{
MEDELLÍN: 50 ANOS ... HISTÓRIA, MEMÓRIA, PROMESSA
}

Medellín: 50 Years ... History, Memory, Promise

Luiz Carlos Sureki *

A dedicação do primeiro número do volume 50 da Perspectiva Teológica à II Conferência Geral do Episcopado Latino-Americano (CELAM) em Medellín, por ocasião dos seus 50 anos, é uma forma de reconhecer explicitamente a capital importância deste evento eclesial para a história e a teologia da Igreja latino-americana e caribenha pós-conciliar. A iniciativa de fazer memória do evento de Medellín soma-se a outras numerosas iniciativas similares (publicações, congressos, debates, etc.) surgidas este ano em toda a América Latina. Se digitamos "Medellín 50 anos" na página do Google, veremos mais de 350 enunciados (só em português e espanhol) imediatamente relacionados ao tema.

A Conferência de Medellín é para a história da Igreja latino-americana um marco indelével, um divisor de águas. Medellín dá início a uma história da Igreja propriamente latino-americana, com tudo o que isso implica cultural, social, eclesial e teologicamente. A memória que hoje fazemos de Medellín não se resume a uma mera lembrança de um acontecimento eclesial importante no passado e para o passado. Trata-se antes de sua atualidade, uma vez que a referência à Medellín é constitutiva da nossa autocompreensão de Igreja e de missão. A promessa, por sua vez, nos remete ao futuro, no sentido de que as grandes intuições de Medellín,

\footnotetext{
* Luiz Carlos Sureki é professor de Teologia Sistemática do Programa de Pós-Graduação em Teologia da Faculdade Jesuíta de Filosofia e Teologia (FAJE), Belo Horizonte - Brasil. Orcid: 0000-0002-9829-3862.
} 
profundamente enraizadas no Evangelho de Jesus Cristo, haverão de continuar a orientar os passos e as opções pastorais desta nossa Igreja.

Em 1999, a Perspectiva Teológica fez memória dos 30 anos da Conferência de Medellín e dos 20 anos da Conferência de Puebla (v. 31, n. 84). Naquele número encontramos um artigo de Cleto Caliman que fala do surgimento de uma nova consciência eclesial na América Latina, a partir de uma visão histórica e crítica da sociedade como sociedade conflitiva, que havia incitado a Igreja latino-americana, animada pelo Concílio Vaticano II, a ensaiar uma nova inserção na sociedade e a se realizar como serviço ao mundo a partir do pobre. Apontava para a permanência de três grandes desafios: a pobreza, agravado pela crescente onda de exclusão social, a reflexão teológica, até então corajosamente empreendida pela teologia da libertação e a formação das comunidades cristãs no horizonte de uma nova consciência missionária (tema que voltou a merecer especial atenção na Conferência de Aparecida em 2007). Ainda naquele volume, Victor Codina escrevia acerca da "teologia latino-americana na encruzilhada", interrogando-se acerca de um possível retrocesso da teologia da libertação, na linha do irrenunciável caminho da opção pelos pobres, crucificados e excluídos, aberto por Medellín.

Embora não se dedicasse um outro número da revista aos 40 anos de Medellín, dedicou-se, contudo, o n. 121, em 2011, aos 40 anos da teologia da libertação. O editorial de então sublinhava a surpresa do "Espírito" em Medellín, no sentido de os bispos terem dado um salto maior do que se esperava, concretizar as orientações do Concílio, e tomado decisões corajosas ao assumirem a opção fundamental da Igreja latino-americana em compreender-se como sujeito de transformação na sociedade latino-americana, proporcionando, assim, a passagem "de uma Igreja-reflexo para uma Igreja-fonte" (cf. Henrique de Lima Vaz - Cadernos Brasileiros, n. 46, 1968) e abrindo espaço para uma expressão teológica mais sintonizada e coerente com tal opção: a teologia da libertação.

Ao fazer uma breve releitura acerca das opções básicas de Medellín, João Batista Libanio (Perspectiva Teológica, n. 105, 2006) resgatava a recepção criativa e a perspicaz originalidade desta Conferência por ter modificado a pergunta fundamental quanto à aplicação dos documentos do Concílio ao contexto latino-americano. A nova pergunta, que não ignorava, mas antes captava o "espírito" do Concílio desde o contexto da Igreja latino-americana, era: que serviço se pode prestar ao povo pobre, num continente de opressão, necessitado de libertação? Ou ainda: que significa, a partir da revelação cristã de Deus, comprometer-se num contexto de América Latina? Com efeito, ao tomar a evangelização à luz das opções básicas do Concílio: o primado da Palavra de Deus, a Igreja como Povo de Deus, a colegialidade, o espírito ecumênico e inter-religioso, a dimensão do serviço, a compreensão ampla de santidade, entre outros, e ao 
encarar os problemas estruturais sócio-político-econômicos subjacentes à pobreza e opressão social do Continente, vendo-julgando-agindo, a Igreja latino-americana deixava para trás uma tradição de mero ensinamento de verdades e de prescrições morais e assumindo uma postura profética nos discursos, práticas, instituição; tomava a sério o enorme problema da injustiça social e a necessária libertação dos pobres, pondo-se, assim, em fiel sintonia com o projeto libertador do Reino de Deus vivido e anunciado por Jesus Cristo. Foi nesta onda de renovação eclesial que ganharam grande impulso as comunidades eclesiais de base (CEBs). Estas buscaram articular vida e fé, compromisso religioso e social; tomaram a Bíblia nas mãos, formaram círculos bíblicos e assumiram a singeleza e a força libertadora do Evangelho de Jesus Cristo.

Assim como as opções básicas de Medellín mantêm estreita relação com as opções básicas do Concílio Vaticano II, também a recepção de Medellín tem algo em comum com a recepção do Concílio. Com efeito, o que ocorreu nas décadas posteriores a Medellín, na Igreja latino-americana, em termos de dificuldades na recepção e de resistências à efetivação das suas opções fundamentais, portanto, à encarnação do espírito dessa Conferência na vida eclesial dos cristãos, não foi muito diferente do que ocorreu nas décadas seguintes ao Concílio Vaticano II na Igreja como um todo em relação à recepção e realização das opções fundamentais daquele Concílio. Medellín fecundou setores da Igreja latino-americana, não toda a Igreja latino-americana, assim como o Concílio fecundou setores da Igreja, não a Igreja como um todo. Ao impulso pastoral-espiritual criativo inicial, "centrífugo", em saída, descentralizante, inovador, logo emergiriam forças contrárias, atitudes doutrinais "centrípetas", de retorno, de centralização, de promoção e manutenção das antigas estruturas eclesiais.

Um bom indício da atitude centralizadora da Igreja de Roma foi sua preocupação com a organização da Conferência de Puebla (1979). Já não se tratava mais de um significativo avançar na esteira aberta por Medellín, mas antes de reconduzir o Continente ao leito seguro do controle institucional de Roma, no campo interno da vida eclesiástica e na atuação da Igreja na sociedade (LIBANIO, 2006, n. 115 supramencionado). "Os teólogos da libertação foram sistematicamente excluídos da assessoria, e a teologia por eles até então gestada no vigor espiritual de Medellín foi tratada como se não existisse", continuava Libanio no mesmo artigo. A opção pelos pobres e sua libertação foi, de certo modo, enfraquecida pelo deslocamento do substantivo "libertação" para o adjetivo evangelização "libertadora" e pela entrada da opção pelos jovens. Deste modo, a ideia de uma estreita relação de continuidade de Medellín em Puebla não é unânime entre os teólogos e estudiosos do tema. Enquanto alguns veem em Puebla um novo vigor para Medellín, outros são do parecer que Puebla "domesticou" Medellín, ou já começava a "frear" o impulso dado à Igreja latino-americana por Medellín. 
Na Conferência Episcopal de Santo Domingo (1992), a Igreja da América Latina teve pouca liberdade de expressão. Esta Conferência se reuniu no clima da memória dos 500 anos do encontro com as Américas (1492) e da Primeira evangelização. Estendeu o pedido de perdão da Igreja aos indígenas e aos negros e se centrou na proposta da Nova Evangelização, expressão esta não isenta de ambiguidades. Das duas opções de fundo, uma tendia a apoiar e incentivar as comunidades eclesiais de base, enquanto a outra preferia insistir nos movimentos apostólicos dos leigos de cunho internacional, matizando, deste modo, a radicalidade da opção preferencial pelos pobres ratificada pelas duas Conferências anteriores.

Os anos posteriores a Santo Domingo se caracterizaram pelo enorme avanço técnico-científico, pela globalização da economia de mercado de produção e consumo em detrimento de outras dimensões da vida social, pelo crescente enfraquecimento dos laços sociais e das instituições em geral. A complexa, confusa, globalizante e não menos excludente "pós-modernidade" já era o grande desafio que a Conferência de Aparecida (2007) deveria enfrentar e tentar superar.

Em Aparecida, a Igreja latino-americana e caribenha se confrontou com uma dupla necessidade: resgatar as opções fundamentais de Medellín, por um lado, e resistir às forças que as vinham minando a décadas, por outro lado. Esta Conferência centrou-se na Vida: vida de nossos povos hoje (cap. I-II); vida de Jesus Cristo - nos discípulos missionários (III-VI); vida de Jesus Cristo - para nossos povos (VII-X). Buscou-se uma renovação do agir evangelizador da Igreja (missão) a partir do núcleo da mensagem evangélica de Jesus Cristo como vida e, desde aí, o seguimento-discipulado de Jesus Cristo: caminho, verdade e vida. Quatro eixos para bem formar o discípulo-missionário foram propostos: o da experiência religiosa (encontro com Cristo), o da vivência comunitária (encontro com os outros), o da formação bíblico-doutrinal (encontro com a Palavra de Deus) e o do compromisso missionário de toda a comunidade, acolhedora, criativa, formativa, celebrativa, missionária, fraterna.

Voltando-se para Jesus Cristo e sua missão, Aparecida apresenta uma cristologia do seguimento com vistas a provocar uma conversão pessoal e pastoral, e, desde aí, o esperado desdobramento em termos de uma renovação das estruturas eclesiais. A expressão "opção pelos pobres" foi conservada verbalmente, ainda que, algumas vezes, se tenha omitido o adjetivo "preferencial" e, em outras, se tenha utilizado o adjetivo "evangélica". Os pobres, aflitos e enfermos foram mencionados como "lugar de encontro com Cristo" (DAp, n. 257). Aparecida preocupou-se em reavivar a consciência do ser cristão a partir do encontro com Cristo, e, desde aí, convidou os cristãos e cristãs a tirar as consequências prático-eclesiais, vale dizer, missionária, do discipulado no horizonte da promoção da vida. Convocou os cristãos a uma Missão Continental num clima de "fervor 
espiritual" (n. 551-522), na alegria que os cristãos deveriam experimentar por serem discípulos e missionários de Jesus Cristo (n. 28-29). Contudo, Aparecida pareceu não ter tomado plena consciência da passividade reinante no espírito de grande parte dos cristãos, já há tempos acostumados com a doutrina cristã, com uma pastoral de mera conservação, como já havia denunciado Medellín (6,1), que os fazia mover-se timidamente no interior de uma Igreja hierárquica, dogmática, centralizadora e clericalizada.

"Lamentamos, seja algumas tentativas de voltar a um certo tipo de eclesiologia e espiritualidade contrárias à renovação do Concílio Vaticano II, seja algumas leituras e aplicações reducionistas da renovação conciliar..." (DAp, n.100). Aparecida reconhecia parcialmente ("algumas tentativas", "algumas leituras") o distanciamento em relação àquelas intuições renovadoras do Concílio, compreensão de Igreja e missão, e de Medellín, opção pelos pobres e libertação, ao mesmo tempo que tentava contornar o problema do centralismo eclesial romano. Por fim, se voltava para Jesus Cristo como princípio teológico estruturador da vida cristã e, por isso, também, de uma possível renovação eclesial-missionária. Os desafios à esta renovação provinham da nova configuração social reinante. Aparecida descreveu a realidade socioeconômica em sua dinâmica atual com a palavra "globalização" (n. 43; 60-73); falou de uma "mudança de época", cujo nível mais profundo é o cultural, e que se faz sentir pela dissolução da concepção integral do ser humano, sobrevalorização da subjetividade individual e consequente individualismo (n. 44); fez menção ao descaso para com o bem comum; apontou para uma nova visão de realidade criada pela ideologia capitalista de mercado, à qual servem a ciência e técnica (n. 45); retratou a problemática sociopolítica no Continente (n. 7482); expressou a preocupação para com o meio-ambiente: biodiversidade, ecologia, Amazônia (n. 83-87); sublinhou a dignidade da mulher (n. 48-49); a presença dos povos indígenas e afro-americanos na Igreja do Continente (n. 88-97), todos temas de indiscutível atualidade.

Ao fazermos memória de Medellín, nos confrontamos com uma gama de temas/problemas ali tratados, que pela complexidade e pertinência para a atualidade mereceriam, cada um deles, uma abordagem histórica aprofundada que aqui, porém, não podemos apresentar. Com efeito, Medellín abordou a problemática da justiça e do trabalho, da família, da política, da paz, da educação, da juventude, da pastoral das massas e das elites, da renovação da catequese, da liturgia, dos movimentos leigos, dos sacerdotes, da formação do clero, dos religiosos, da pobreza da Igreja, dos meios de comunicação social. Aqui nos contentamos em assinalar muito brevemente a atualidade da Conferência de Medellín, na perspectiva de continuidade com o Concílio Vaticano II e com o impulso que a Igreja tem recebido no pontificado do Papa Francisco, sob três aspectos abrangentes: eclesial, antropológico-pastoral e profético. 
Com relação à eclesiologia percebemos em Medellín o desejo de que a Igreja Povo de Deus (LG, n. 9-17) seja também a Igreja pobre e dos pobres, e assim, uma Igreja de todos. Neste sentido, o Papa Francisco vem insistindo na necessidade de uma Igreja simples, despojada, humilde, mais livre, mais leve, mais disponível, mais em sintonia com o Cristo pobre com os pobres e mais atenta aos desafios e possibilidades dos novos tempos. Uma certa preocupação com clero já encontramos em Medellín: “Exortamos os sacerdotes a darem, também, testemunho de pobreza e desprendimento dos bens materiais como o fazem tantos, particularmente, em regiões rurais e em bairros pobres" (Medellín, 14,15). Tal exortação mantém sua plena atualidade. Não é difícil constatar, hoje, no ambiente clerical, especialmente entre os jovens presbíteros, a forte tendência de buscar status eclesial, conforto material e segurança institucional. O espírito carreirista, individualista e consumista sufoca a sensibilidade para com os pobres e $\mathrm{o}$ interesse pela problemática social.

Ao aprofundar a opção pelo ser humano e sua dignidade (GS, n. 3-4; 12-22), Medellín concluiu que ela deve nos conduzir, de modo mais concreto, à opção preferencial pelos pobres. "A promoção humana será a perspectiva de nossa ação em favor do pobre, respeitado em sua dignidade pessoal e ensinando-lhe a ajudar-se a si mesmo" (Medellín 14,40). Em nosso atual contexto, os pobres se tornaram descartáveis no interior de um gigantesco mercado de produção e consumo alimentado por uma economia neoliberal excludente. A opção pelos pobres, radicada na fé cristológica, precisa hoje, talvez mais do que nunca, ter mais visibilidade na configuração da Igreja. O desejo de uma Igreja como "hospital de campanha", o ministério pastoral como tratamento das feridas, a fé cristã como caminho, "em saída" ao encontro do outro, a atitude samaritana, imagens que o Papa Francisco tem utilizado em seu pontificado, certamente têm em Medellín suas raízes.

Por fim, o caráter profético de Medellín se diz especialmente em relação à diaconia histórica da Igreja, ou seja, ao seu serviço ao mundo (GS, n. 42), à sua contribuição para o progresso e o desenvolvimento humano e social (GS, n. 43). A diaconia se concretiza na denúncia da injustiça e da opressão. A missão evangelizadora se reveste de um caráter profético, quando se mostra como sinal de contradição. Com efeito, a opção pelos pobres não pode ser confundida com assistencialismo ingênuo que não leva em conta as verdadeiras causas da pobreza, nem as denuncia, que não suscita mártires, que não gera compromisso, que não tem cruz, nem dor, nem conflito. Quando a Igreja se acomoda à situação de injustiça torna-se sem voz e logo, também, sem ouvintes. Para dizer com o Papa Francisco: "Se acontecesse alguma vez que a Igreja não levasse a Jesus, essa seria uma Igreja morta" (homilias em Santa Marta), sem espírito profético.

Enfim, fazer memória dos 50 anos de Medellín é excelente oportunidade de deixar-nos envolver pelo Espírito divino que soprou vida à Igreja 
latino-americana e que inspirou uma teologia alimentada pela práxis, pela força transformadora do Reinado de Deus, a Boa Nova trazida por Jesus Cristo. Os desafios referentes à pobreza, à reflexão teológica corajosa e à formação das comunidades cristãs à altura da nova consciência eclesial-missionária, inaugurada em Medellín e retomada em Aparecida, continuam muito presentes. Junto a eles e por causa deles, surge com frequência a tentação de se buscar refúgio nas velhas seguranças de um cristianismo pré-moderno: criar grupos e movimentos conservadores, insistir na manutenção de "estruturas caducas", para dizer com Papa Francisco, centrar-se tão somente na exterioridade do culto e da ação litúrgica, restituir ou promover os devocionismos populares antigos que nada tem a ver com a religiosidade popular e com o sensus fidei, entre outros. É certo que vivemos em meio a uma situação marcada pela desorientação, pela crise dos grandes ideais que haviam impulsionado a civilização moderna ocidental. Mas é, justamente aí, neste contexto histórico "líquido", sem porto seguro para se ficar ancorado, que os cristãos se veem impelidos pelo vigor do projeto de Jesus Cristo e pela liberdade do Espírito de Deus a singrar novos mares, a lançar redes mesmo em águas turbulentas. "Os que são conduzidos pelo Espírito de Deus, estes é que são filhos de Deus: vós não recebestes um espírito que vos torne escravos e vos reconduza ao medo, mas um Espírito que faz de vós filhos adotivos e pelo qual nós clamamos Abbá, Pai" (Rm 8,15). 